IRA-International Journal of Management \& Social Sciences

ISSN 2455-2267; Vol.06, Issue 01 (2017)

Pg. no. 118-129

Institute of Research Advances

http://research-advances.org/index.php/RAJMSS

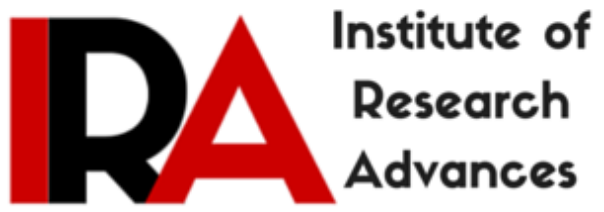

\title{
Operation of Local Government Transparency in South Sulawesi Province, Indonesia
}

\author{
A. Jamaluddin \\ High School of Social and Political Sciences (STISIP) Muhammadiyah Sinjai, Sulawesi \\ Selatan 92615, Indonesia.
}

Type of Review: Peer Reviewed.

DOI: http://dx.doi.org/10.21013/jmss.v6.n1.p16

\section{How to cite this paper:}

Jamaluddin, A. (2017). Operation of Local Government Transparency in South Sulawesi Province, Indonesia. IRA-International Journal of Management \& Social Sciences (ISSN 24552267), 6(1), 118-129. doi:http://dx.doi.org/10.21013/jmss.v6.n1.p16

(C) Institute of Research Advances

\section{(cc) EY-NC}

This work is licensed under a Creative Commons Attribution-Non Commercial 4.0 International License subject to proper citation to the publication source of the work.

Disclaimer: The scholarly papers as reviewed and published by the Institute of Research Advances (IRA) are the views and opinions of their respective authors and are not the views or opinions of the IRA. The IRA disclaims of any harm or loss caused due to the published content to any party. 


\begin{abstract}
Transparency in South Sulawesi Provincial Government has been applied in efforts to achieve good governance. The problems of this research are; (1) how to transparency in local governance, (2) what factors inhibiting transparency in local governance, and (3) what is the right strategy is used in implementing the transparency of the regional administration. This study aims to: 1) describe the transparency in local governance, 2) analyze the factors that become an obstacle to transparency in local governance, and 3) to apply the right strategy in the transparency of the regional administration. The study found that transparency in governance has been run as expected in the areas of budget, staffing, procurement of goods and services. Human resources mentality of corruption, overlapping rules, the financial system is weak, weak law enforcement and a tolerant society are all factors that become an obstacle to transparency in local governance. Transparency strategy is appropriate intensive use in implementing the transparency of the regional administration. Through this model of good governance transparency can be realized as a solution to overcome the problems of the dynamics of government activity that is not transparent and minimize the factors inhibiting the realization of good governance transparency.
\end{abstract}

Keywords: Transparency, Obstacles, Transparency Strategies

\title{
Introduction
}

The success of national development cannot be separated from the involvement of the government and the community to jointly undertake the development process planned, directed and purposeful. On this basis, the required contribution from the government and the community to work together in conducting national development. One of the successes of the government and the public to engage in national development cannot be separated from the ability to understand the government that is transparent and public support for ensuring good governance.

Government that is transparent or open a system adopted by the Government in carrying out its activities there is free flow of information in various institutional processes of each agency working units (SKPD), making it easily accessible to every strata of society. Various information is held, given and provided by the Government are accessible can be used as a tool for monitoring, evaluating and assessing the work done by the government under the supervision of the community.

Regional Government of South Sulawesi province after the reform era are required to be more transparent to the various activities of governance created by the government and has the support of the community by creating all the tools and rules of the system and mechanism of action of the government must be transparent, informed to the community and society easy access to all information relating to good governance in accordance duties and functions of each government agency. Transparency in principle is the principle of the creation of mutual confidence between the government and the public through the provision of information that ensures the ease in obtaining accurate information and adequate. Through this transparency, government and communities together to provide information where the information is a necessity for governments and communities to mutually participate in running good governance.

Moving on from the understanding of transparency, the Regional Government seeks to achieve transparency of regional governance by conducting a series of activities of good governance, so that the confidence of the community to take over management of government in favor of the community. The basic instrument of transparency of the regional administration is a law that guarantees the right of every citizen to obtain information, while supporting instruments measure of transparency is the facility data base and information tool used to collect all suggestions, feedback and complaints to improve good 
governance.

South Sulawesi Government has set up the governance clear about how to obtain the information needed by the community that can be accessed or information that is updated required by the community and help the government to solve the various problems it faces. Through a fundamental instrument of transparency of information, communication, facility data base and products / services related to the implementation of good local governance, the transparency is a guarantee for governing the right of every citizen to gain access to and dissemination of information on the results of the work of government. Therefore, transparency in government is authorized for the government to advance and develop the support and participation of the people running the government area.

Given the importance of transparency, transparency is solution good governance (Stelent, 2008). Good governance always prioritizing transparency (Wilson, 2007). Transparency and good governance is a unity that cannot be separated. Transparency may not be applicable to government that is not good, and transparency is applied to good governance. On this basis it into consideration to understand the existence of transparency in the application of good governance (Henry, 1995).

The views mentioned above become footing researchers to observe phenomena of transparency in Local Government in efforts to achieve good governance. Problems often occur in transparency or implicated both the government and the society is transparency that is applied in the budget area, the field of personnel and the procurement of goods and services. All three fields in this administration often get the spotlight, protests, complaints and antipathy from the community on areas of work by governments that are not transparent in providing information, communication, access to data, documents and various reporting cannot be judged by the public. Moving on from the phenomenon government is not transparent on the budget, personnel and procurement of goods and services, the effect of mistrust, disagreements, uncertainties and lack of guarantee of the government to achieve good governance. This can be reflected in the habit of government that does not hear the voice of the people or neglect any public input on activities of the tasks and functions of government in running the field in question.

The fact is visible in the field of the budget shows that the government is often not transparent in providing information, and access to public documents relating to results source of income, expenditure and financing revenues derived from state and local budgets are used. It is often a lack of transparency in the budget is the proposal of the General Budget Policy (KUA), Priorities and Budget Ceiling While (PPAS) as well as the discussion stage of the Draft Budget and Expenditure. In the area of the budget is the people often suspect a variety of information that is not transparent, can be done by the government as the executive and the Regional Representatives Council (DPRD) as the legislature to do the engineering of information or misuse of funds in accordance with the information generated agree that the management of the field run budget is not transparent accepted by society.

Besides allegedly by many people that transparency in the field of personnel frequent practice of corruption, collusion and nepotism (KKN), particularly the government is not transparent in the activities of recruitment of civil servants, mutation employee and compensation payments are sometimes not in accordance with the policies and rules apply. Transparency in the field of personnel often interfered with by those authorities who have particular interests and seeking personal gain from not transparent. Understanding this, the people often protest and mengelukan symptoms ketidaktransparansian undertaken by the government by not providing the information, the data document the legality of the law.

Included also in this case the activities undertaken by the government are often the focus of attention of society namely concerning not transparent in the procurement of goods and services, where governments often propose the procurement of goods and services that are not in accordance with the designation, doing various activities mark-up for profit, manipulate the data inventory demand and supply of goods and services, there is a game between the government of corruption conspiracy with entrepreneurs or 
merchants in the procurement of goods and services, so a lot of information, data and documents that are not transparent is a problem in realizing good governance transparency.

Transparent phenomenon in the area of the budget, personnel, procurement of goods and services, would be a fact which should be based on the fact that can be observed and witnessed in various main tasks and functions of government employees. The cause of not transparent in various fields mentioned above, this is because there are factors that impede the transparency of regional governance that is clean, dignified and responsible. Based on the observations found in the world of government that the inhibiting factors of transparency is usually due to existing resources in many governance-minded corruption, government officials have ignored and violated the rules, so as to avoid overlapping rules applied, otherwise the system weak financial management, law enforcement deviated well as the existence of a tolerant society promotes a culture that is not transparent.

The following are the human resources of the employees' mentality corruption often perform duties and functions with no transparency. Consequently, many of the tasks and functions are distorted, are not in accordance with the systems and mechanisms, engineered and create distortions that harm the state and society. In addition, factors inhibiting the transparency of local government processes can occur due to work rules or regulations implementing the duties often overlap, so that the gap used to do things that are not transparent for the personal benefit of the persons in the government. Including factors that hinder the transparency of good governance is the implementation of the financial management system that is not transparent, particularly with regard to the procurement sources of income, expenditure and financing finances frequent irregularities, leakages and abuse because of the poor level of transparency by Governments and make it difficult for people to keep an eye on it because they do not get accurate information and data from the government.

On the other hand the factors that hinder the transparency of government administration is weak enforcement of laws to parties committing violations and impunity, so there is no deterrent effect which caused government officials to do things that are not transparent. In addition, they found among the public in practice making a habit or culture often give to the authorities on a wide range of services or the execution of work despite having a motive as a favor, but it has become a bad habit that can impede good governance transparency materialized.

Through an understanding of the factors that hamper consisting of human resources mentality of corruption, overlapping rules, the financial system is not managed properly, weak law enforcement and public tolerance that makes a habit of giving to unscrupulous employees of the government is a barrier in the difficulty of transparency realized with good. Therefore we need a strategy to implement good governance transparency.

The implementation strategy of transparency of governance of which need to be applied to realize clean transparency, dignified and responsible, fair and equitable, then it can apply the strategy of institutional strengthening, improvement strategies professionalism of human resources, pursuing a strategy of oversight and accountability and encourage the implementation of the strategy of healthy competition in work. This strategy is important in order to realize good governance transparency. Institutional strengthening strategies necessary for transparency in each SKPD government. The realization of the institutional strengthening strategy is an attempt to do the coordination, cooperation and improvement of working relationships between organizations, inter-group and inter-group agencies target destination in order to avoid work systems and procedures that are not transparent are usually carried out by government officials.

Professionalism of human resources strategy is also an effort to achieve transparency may be made by any employee in a government agency to a professional in carrying out its activities in accordance with the 
competence and professionalism of the work that has, thus reducing the gap working practices are not transparent. In addition to the above mentioned strategies, should also be applied strategy oversight and accountability to each employee of each SKPD government agencies to be supervised directly and indirectly, and be held responsible directly and indirectly for all the activities the tasks and functions to be performed transparent in order to improve governance supervised and held accountable.

Including strategies that need to be applied in efforts to achieve transparency of the regional administration is implementing a strategy of healthy competition for each employee in each SKPD to positions of structural, functional and technical through a healthy competition among employees in performing their duties and functions in government, Through healthy competition for competent and excel in order to reduce and avoid non-transparent work activities of government officials who run the activities are not transparent.

\section{Literature Review}

Before explaining the concept of transparency in local governance, the first study described the foundation of transparency itself. Assessment of transparency is the scope of the study of the science of public administration. It becomes important to understand the existence of the concept of transparency as part of the application of public administration. Because it needs to be understood in advance of the public administration theory. Administration theory is inseparable from the construction of public administration. The meaning and function of the construction of public administration theory is learned much more than simply understands the thoughts of a man known as administrative experts who gave birth to various administrative theories, which seemed to be thinking is an ultimate truth. The exact theory is always evolving and knows no end (Rachmat, 2009: 29).

Science covers a very broad field and multidimensional, covering all aspects of human progress as a whole. Therefore, the knowledge that has been formulated systemically through observations and experiments are ongoing, and has resulted in the discovery of truth that is universal. Thus the main characteristic of a science is to have a theory (Rachmat, 2009: 36).

Prior to clarify the concept of transparency is necessary to examine the concept of good governance or can be called Good Governance. The concept of good governance is still debatable and indeed continued to grow in a variety of academic debate. At first the World Bank defines -Governance- as -the exercise of political power to manage a nation's affair (Davis and Keating, 2000). The World Bank also added a normative characteristics of good governance, namely: "An efficient public service, and an independent judicial system and the legal frame work to enforce the contract; the accountable administration of public funds; an independent public auditor, responsible to a representative Legislature; respect for law and human rights at all levels of government; a pluralistic institutional structure; and free press".

Meanwhile UNDP defines good governance as "The Exercise of political, economic, and administrative authority to manage the nation's affairs at all levels. OECD and WB equalize Good Governance to the implementation of development management of solid and responsible in line with the democracy and globalization, the avoidance of misallocation of investment funds are scarce, and the prevention of corruption both political and administrative, run budgetary discipline and creating legal certainty and the political atmosphere for the growth of entrepreneurial activity.

In the reform era in which the pillars of good governance have become an urgent matter in the life of the nation, then it was also the transparency of governance has become a necessity that cannot be ignored anymore. A key issue and becomes a question of this study is why it needs to be transparency in the Good Governance? Therefore, before any further attempt to find the format and concept of transparency may be the above questions need to be answered first. 
The responsible government is the government that is able to answer or fulfill a promise to the public and their constituents. To realize the government accountable to the public, so one way to do is to use the openness principles of transparency. Transparency of governance has a very important meaning in which people are given the opportunity to know the policies that will be and have been taken by the government. Even with the transparency of the government administration, the public can provide feedback or outcomes of the policy that has been taken by the government.

This means that transparency in governance can give meaning meant that besides being one form of accountability of government to the people, but it also can create good governance or good governance and can also reduce the chance of collusion, corruption and nepotism (KKN). Here is the key why transparency is needed in Good Governance in fact is one of the important conditions. Probably still fresh in your mind, that one being the issue of the end of the period of the new order is the proliferation of corruption cases. And one that can cause and give space for this activity is the management of government that is not transparent.

The application of transparency in local governance exertion intended that every activity of government administration is done through the provision of information in an open and supervised by all parties, including in this case the community. Disclosure of information and broad oversight becomes essential to achieve transparency in local governance. Transparency in local governance should be open, accessible, accountable and able to provide information in accordance clarity and monitored extensively by all parties involved in local governance (Sedarmayanti, 2008: 57).

Transparency is an important instrument for ensuring good governance, clean and dignified. Transparency is the core of the concept of good governance. Actualization of transparency is transparency, accountability; access to information is clear and can be assessed broadly by all parties in order to realize good governance. Transparency at the core of the success of good governance, clean and prestigious depends on; (1) the transparency of government budget management; (2) transparency of government behavior management; and (3) the transparency of government procurement. The third form of transparency is crucial to the success or failure of governance (Dwiyanto, 2008: 75).

Common problems in the Indonesian bureaucracy and the fact that it encountered, identify the factors inhibiting implementing on principles of transparency in the public service as follows: Lack of human resource competence starting from recruitment that is not true because poor recruitment system. This continues with the development of human resources is also not good. The number of cases of the occurrence of corrupt practices in the recruitment of civil servant in various agencies and local government performed poorly in the system of recruitment of civil servants. Appointment of nearly one million workers salaries as civil servants through a selection process that is not an obvious example waiver competence. If this was offset by good coaching, it will be able to reduce their negative impact. But if it is not followed with adequate guidance, then the impact will be very bad in the future.

The elimination of the overlap causes a disguise or conceals official duties and functions by accentuating its authority. This is clearly contrary to the principle of transparency. Overlapping of these regulations is also heavily influenced by political factors and the legislative and of the executive alone. The monitoring system, monitoring, and evaluation weak will not be able to uncover weaknesses and irregularities that occur in an activity, including non-compliance with the rules and the necessity to implement the principles of transparency.

Often some deviations are not being accepted appropriate measures, with a variety of considerations. This resulted in similar error can occur repeatedly. Results of supervision, including oversight of the community in the form of complaints were not followed will make the supervision itself is useless. It makes society so apathetic community supervision to be not working. It is a lot going where when people 
already feel familiar with the occurrence of irregularities that was never dealt with. Thus, the surveillance society wills no longer function as it should. It is also due to the understanding of the noble values of religion are wrong.

The implementation strategy of local government transparency through some aspects of the driving factor of transparency: first, institutional strengthening. Appropriate institutional functions and precise sizes and does not overlap with the clear will be identified who should be responsible even need to be given sanctions in case of irregularities or failure to achieve performance targets. Second, professionalism (HR), partial and civil servants who are officials always maintain professionalism. Parties that must be maintained and with developed, reward should be, so it can be followed by other civil servants. Thirdly, oversight and accountability of the money followed system of a reward and punishment. Some institutions have implemented systems money that bags us so that the performance of these agencies is quite nice. Commitment is what needs to be transmitted to other agencies. And fourth, a healthy environment.

Competition among local governments in certain respects will encourage each to improve performance (public service) to always make improvements through property against any feedback, especially from people who use the service. Rate the performance of a particular sector by the Institute's Independent will indirectly encourage competition among local governments and agencies to achieve the desired ranking minister also mandated by law to rank public service providers, has been done with the image of Service Excellence award. It will also enliven the level of competition among providers of public services.

\section{Methodology}

This research uses a qualitative research approach assessment methods (study) that describe various phenomena, researchers did not use statistical procedures but inductively in which the researcher as its main instrument. Qualitative research is used because it can reveal the real events on the ground and also reveals the hidden value (hidden value) from this study.

Qualitative research is expected to direct the research to get the answers ontological, that of meaning and urgency observations. This research is directed to aspects epistemologies namely to assess the urgency of observation. Included also observed aspects axiology to benefit or observations. Observations in question in this case are transparency in local governance.

The research approach used is a method of study. This study examines specific, detailed and in-depth about the problems with finding as much information as possible in order to reveal a phenomenon that became the basis for the selection of research (Strauss and Corbin, 1990). Informants in this study are SKPD as Chief Executive, members of parliament as legislators, NGOs and Community Leaders.

The use of the instrument in qualitative research always refers to an instrument that indicates the capacity of individual researchers. Therefore, being instruments in these researchers are researchers themselves (human instrument). As the main instrument, the researcher must override the various matters relating to forms of prejudice, prejudice and assumptions derived from research participants or informants. In order to process data collection, there are three activities carried out by researchers is getting in, getting along and logging the data is in the form of in-depth interviews, observation and documentation.

Data analysis techniques used in this study includes a series of data handling activities starting from the stage of collecting data and then analyzed the data according to the stages of data reduction and data presentation, data verification and data reduction. 


\section{Discussion and Analysis}

Describe the existence and substance of transparency of the regional administration in detail about the implementation of transparency in the area of the budget, staffing the field of transparency, the transparency of the procurement of goods and services, which cannot be separated from the factors that hinder the establishment of transparency, can be applied properly. Factors inhibiting transparency based on the results of this study consisted of human mental, overlapping regulations, the financial system is not managed well, weak law enforcement and a tolerant society to carry out practices that do not support the strengthening of transparency. Therefore we need an implementation strategy through the strengthening of institutional transparency, professionalism of human resources, oversight and accountability and fair competition.

Transparency applied in this study is the transparency of the regional administration, where transparency in this research is the public open access to obtain information on the various activities undertaken by the government. Transparency in this study are the principles that guarantee access or the freedom for everyone to obtain information about government administration, information on governance, information about the main tasks and functions of the government, the process of governance in various areas of work. Transparency applied in this study is the openness of the government in making good governance in governance, so that every process of governance is done can be seen by the public. Transparency in turn creates a clean government, authoritative, fair and equitable.

Transparency is run by the government in providing information related to the activities of governance in general and governance in particular on the budget, personnel and procurement. In principle goal of transparency in local governance do aim to: 1) creating government accountability in the conduct of governance to the people; 2) efforts to increase public confidence in the ability of the government in the management of good governance; and 3) in an effort to improve the government's ability to govern is not corruption, collusion and nepotism.

Based on the discussion outlined above, supported by transparency theory put forward by Frederickson (2007) that transparency is done in earnest, thorough, and make room for the active participation of all segments of society in the process of governance and public. This theory asserts that the transparency required by the government and public participation to good governance. Leach and Pelkey (2001) that transparency means openness and honesty to the public based on the consideration that the public has a right to find out openly and comprehensively on government responsibility entrusted by the rules and laws. This is in line with the views expressed; transparency is a form of public confidence in the accountability of the activities undertaken in accordance with the rules (Syafei, 2002).

Understanding the importance of transparency in local governance, supported by the implementation of the transparency dimension, this theory has the principle that every person has the right to obtain guaranteed access to freedom of information and data as well as reporting on the administration of government. Information about policies, governance activities, policy making, implementation and results of work achieved an important part of the implementation process transparency (Billig, 2008).

In essence transparency regarding matters that are openness, freedom and the applicable rules should be known by all levels of society on an overview of the rules and principles of governance. Transparency is an event or events that are free and open unknown by the general public; transparency is a directness that corresponds with the reality of the information submitted and verifiable truth (Deighton- Smith, 2004; Shah, 2008). Understand the transparency of the support of expert opinion is relevant to the implementation of the transparency of governance relating to the transparency of the financial sector, transparency field of personnel and transparency in the procurement of goods and services. Budget transparency is disclosure of various information, data and support and reporting that can be studied and assessed by the public to be interpreted in an honest and trustworthy (Rondinelli, 2007). 
The transparency of the budget is activity assessment activities, calculation and reporting of financial budget is carried out in accordance events, incidents and transactions within financial systems and procedures (Caiden, 2006). An understanding of the staffing transparency, transparency is in line with the theory of human model that every human being requires transparency in assessing the model ability in accordance with the interpretation and openness about the competence, expertise and professionalism (Andrew Simon, 2008). On that basis then everyone should be able to develop their potential in a transparent manner to known the competence, expertise and professionalism has. It is important to make it easier to assess the feasibility of recruiting someone to be transferred by a strategic position to be considered in accordance with the magnitude of competence decent and deserved by someone. Besides understanding the transparency of procurement of goods and services is supported by a wealth of organizational theory. An asset of the organization in the form of goods and services is a wealth of organizations that should be used to achieve organizational goals. This means that the existence of the procurement of goods and services is indispensable as an important asset to the organization (Halpern and Pagliari, 2007).

The asset in the form of goods and services is a basic capital organization to realize its objectives (Teune, 1995). This means that the procurement of goods and services is indispensable for the survival of the organization, but must be applied in a transparent manner, so that makes it easier to assess the utilization and use of assets to realize the objectives of the organization. The application of the transparency of the regional administration carried out in the regional government, not apart from factors that support and hinder. Factors that support becomes important to observe, because it does not cause problems in the application of transparency, but a limiting factor becomes important to be observed, so that in the handling of transparency can be contained and controlled to achieve good governance transparency.

Factors inhibiting transparency of the regional administration is certainly a lot of factors, but the factors that urgent found in various dynamics of the government is always concerned by a factor of existence of human resources that mentality of corruption, application of the rules which always overlap, application of the financial system is weak, weak law enforcement and habits tolerant society to perform actions that are not transparent with the government. Understanding of the factors inhibiting the realization of good governance transparency inseparable from factors inhibiting transparency in government administration. These factors, if not anticipated or properly handled can affect the organization's activities are run by nontransparent (Flippo, 2002).

After application of the transparency of good governance in the transparency of the budget, personnel, procurement of goods and services, a variety of factors that impede the transparency of human resource factors that mentality of corruption, overlapping regulations, the financial system is weak, law enforcement and tolerant society on the habit of giving and receiving as obstacles that must be addressed and improved to achieve transparency for good governance, so there needs to be a strategy of transparency to be used in creating the transparency that is easily applied by the government and for the public to obtain a variety of information, data, documents and reports for the various subject on main tasks and functions of government are carried out in a transparent manner.

Implementation of the strategy adopted to achieve good governance include transparency of institutional strengthening strategies, human resource improvement strategies professionalism of government, oversight and accountability, strategy and development strategy of healthy competition among government officials in performing their duties and functions are transparent. The realization of this transparency strategy can solve various problems of government transparency through good socialization applied to the Local Government. Strategy seen by objectives and targets to be achieved. The strategy is expressed as the establishment of long-term objectives and goals of an organization as well as the use of a series of actions and allocation of resources necessary to achieve organizational goals (Salusu, 2005). 
There are four important attributes within an organization to actualize transparency are the skills, resources, and environmental objectives (Mc Nichols, 2002). The strategy is part of the overall action defined as rules that have been planned by an organization, that the strategy is implemented according to the pattern of interest that the aims and objectives, based on public policy and planning (Learned et al.; Shirley in Salusu, 2005). Essentially action strategy is to expand the mission; goals and objectives of the organization are also pursuing a policy based on the program and ensure the creation of planning in making organizational decisions in a transparent manner (Steiner et al., 1989)

Implementation of the strategy of some expert opinion that stated above becomes a comparison to implement a strategy of transparency that is appropriate in the regional administration as research proposals that are solutions to the problems experienced by local government processes are not transparent, so it is necessary to apply "Transparency Partial". Implementation strategy model "partial transparency" is interpreted that the application needs to be done in partial transparency, particularly transparency in the financial field, field personnel and field of goods / services. Implementation of the strategy of "partial transparency" becomes important in the organization of transparent government, where the government should provide access to information that is easy, simple and uncomplicated for all parties, governments, communities and other stakeholders. It is important that access through the various issues related to the activities carried out by local governments can be seen, assessed, reported and supervised, so that the activities of governance can walk with transparent access to information.

Transparency of governance in its application requires the full support or empathy from the public or the public, because it is empathy become important in achieving transparency. The importance of empathy in transparency is the growing understanding or the emergence of initiatives to carry out various activities of governance in favor of the public interest and priority alignments to the public or the public, so that all the activities of the government receives the empathy of all parties.

Create transparency of governance cannot be separated from moral contribution of everyone involved in governance. Moral of every person is a very important ethical value in the application of transparency. Through a transparent moral an added value in building public trust to be able to carry out all activities in a transparent administration with the practice of moral values in accordance with the ethical propriety, decency and proportionate in expanding duty as a mandate to be carried out transparently. Inflate a duty to achieve transparency of good governance, can take place when any decisions are carried aspiration. The application of transparency should be done aspiration as a democratic process to listen or accept any input public aspirations impact on confidence or belief that the government runs a government organization conducted aspirated from the public and for the public.

Realizing the implementation of good transparency, not in spite of the importance of the minutes is a record that contains important documents that should be informed, reported and accounted for any activity carried out by the government in a transparent manner and it was recorded and used as an essential document to evaluate or assess the various feedback, criticisms, suggestions and proposals from each community from the village, district and government and private agencies that support the realization of good governance transparency. Understanding the strategy of "Transparency Partial", then support governments, communities and other stakeholders to carry out activities of transparency both in the areas of finance, personnel and goods / services must be done by considering the transparency accessible, transparency empathize with the public interest, transparency moral, transparency aspiration and transparency records. Through the "partial transparency", the government organization capable of carrying out all the activities of government activities in a transparent manner. 


\section{Conclusion}

Based on the results summarized as follows: 1) transparency in governance has been run as expected in the areas of budget, staffing, procurement of goods and services. This is seen in the field of the budget has been carried out the process of transparency in public policy development budget, while the budget priorities and ceiling as well as the stage of discussion of the draft budget revenues and expenditures is not clear in reporting; field of personnel in the form of recruitment activities, transfer and compensation; as well as the procurement of goods and services in the form of an inventory of assets, conducting the legality audit, asset valuation, asset optimization, as well as surveillance and control activities, which is still not up to the implementation of transparency in local governance; 2) human resources mentality of corruption, overlapping rules, the financial system is weak, weak law enforcement and a tolerant society are all factors that become an obstacle to transparency in local governance; 3) strategy "partial transparency" be the right solution used in implementing the transparency of the regional administration. Through this model of good governance transparency can be realized through access to information that is readily available, get full of public empathy, moral repair public trust, accept the aspirations of the public and have the minutes that can be accounted for.

\section{References}

1. Andrew, S. 2008. Governance by agreements: Why do local governments enter into multilateral agreements?. Working Group on Interlocal Services Cooperation, 37.

2. Billig, M. 2008. Nominalizing and de-nominalizing: a reply. Discourse \& Society, 19(6), 829841.

3. Caiden, G. 2006. The administrative state in a globalizing world: some trends and challenges. In Comparative Public Administration. 515-542. Emerald Group Publishing Limited.

4. Davis, Glyn and Keating, Michae. 2000. Future of governance : policy choices. Published St Leonards, N.S.W. : Allen \& Unwin

5. Deighton Smith, R. 2004. Regulatory transparency in OECD countries: overview, trends and challenges. Australian Journal of Public Administration, 63(1), 66-73.

6. Dwiyanto, Agus. 2008. Realizing Good Governance through public service. Yogyakarta : Gadjah Mada University Press.

7. Edwin B. Flippo, 2002. Personel Management, Ed. VII Vol. II, Translation. Alponso S, Erlangga, Jakarta

8. Frederickson, H. George, 2007. Toward a New Public Administration. Revision Edition. The Minnowbrok Perspective Novato Chancler Publishing Company

9. Halpern, N., and Pagliari, R. 2007. Governance structures and the market orientation of airports in Europe's peripheral areas. Journal of Air Transport Management, 13(6), 376-382.

10. Henry, F, 1995. The Public Service Administration. New York: Free Press.

11. Leach, W. D and Pelkey, N. W. 2001. Making watershed partnerships work: a review of the empirical literature. Journal of water resources planning and management, 127(6), 378-385.

12. McNichols , M.F. 2002. Discussion of Quality of Accruals and Earnings: The role of accrual estimation errors. The Accounting Review, 77(4) 61-69.

13. Rakhmat, Sartono, 2009. Understanding Good Governance in partnership with the public. PT. Grafindo Persada. Jakarta

14. Rondinelli, D. A. (Ed.). 2007. Public administration and democratic governance: Governments serving citizens. UN.

15. Salusu, J. 2005. Strategic decision making For Public and Non Profit Organization, PT. Grasindo, Jakarta.

16. Sedarmayanti. 2008, Human Resource Management, PT. Refika Aditama, Bandung

17. Shah, M. 2008. Governance reform key to NREGA success. Governance, 14, 3-08. 
18. Steiner, GA, JR Miner, and ER Grey 1989. Management Policy and Strategy. Text, Readings and Cases. ed. 3. New York. Macmillan

19. Stelent, RF, 2008. The Service of Policy in Organization. John Wiley and Sons, New York.

20. Strauss, Anselm and Corbin, Juliet. 1990. Basis of Qualitative Research: Grounded Theory Procedure and Techniques. London: Sage Publications,

21. Syafei, Kencana Inu, 2002, The System Of Indonesia Government, Rineka Cipta. Jakarta

22. Teune, H. 1995. Local government and democratic political development. The Annals of the American Academy of Political and Social Science, 540(1), 11-23.

23. Wilson, Wayne, 2007. A Introduction of Theory and Practice of Public Analysis. Northampton: Edward Elgar. 